\title{
Financial Instruments to Increase the Ecological Safety
}

\author{
Svetlana Izmailovich \\ Department of Economics \\ Polotsk State University \\ Novopolotsk, Republic of Belarus \\ dsd1095@yandex.ru
}

\author{
Aydin Rahmanov \\ Vice Chairman of the Supervisery Board \\ of Insurance Companies \\ Qala Life and Qala Insurance \\ Baku, Azerbaijan \\ a.rahmanov@qala.az
}

\begin{abstract}
This article justifies, that questions of environmental protection, protection of natural resources, ecological safety are the most actual for effective development of economic systems. In the modern economic situation, coherence and administrative leverage in total with ecological taxation and insurance are forceful instruments to move towards the model of «green» economy.

The main goal is to consult the theoretical and practical experience of formation the ecological safety under the paradigm of «green» economy of European countries and the Republic of Belarus based on analysis of main financial instruments of the state ecological policy.

The main tasks are: identifying mechanism of formation of ecological safety in conditions of green economy in European countries and in the Republic of Belarus; identify and systematization of main financial instruments for state ecological policy; justification of necessity and directions for improvement the ecological taxation and insurance.

Methodology of the study is based on the principles of the system analysis, formal logic and interdisciplinary scientific approach to the problem. Monographic and descriptive method, method of analysis and synthesis, statistical data analysis method were used to complete the tasks of research.

Novelty of this research is that systematization of theoretical practical foundations of state management of ecological safety through financial instruments of green economy can increase the effectiveness of the stable development of the economic system.
\end{abstract}

Keywords-Financial mechanism, insurance, leverage, methods, policy, security, structure, tools, taxes.

\section{INTRODUCTION}

The problems of the environmental protection occupy a more prominent position in the system of the world priorities. At present, we can note the great international attention to improving the efficiency of environmental activities, especially in developed countries and large regional economic blocs, in which environmental values are actively embodied in economic development strategies, which makes it possible to very successfully solve environmental safety problems.Many countries use a wide arsenal of funds, both legislative and economic measures, including financial ones, when carrying out environmental protection policies.In this regard, it is particularly relevant to study the financial mechanism for ensuring environmental safety.

\section{Materials and Methods}

Research methodologies for environmentaleconomic interactions emerged in the second half of the 20th century as a result of a sharp exacerbation of environmental problems. A significant contribution to the study of these problems was made by the works of scientists of the Rome Club, such as D. Meadows, A. Peccei and J. Forrester [1]. The works of the outstanding Russian scientist V.I. Vernadsky [2] served as the starting point of many global environmental studies.

Based on documents UN, UNEP, OECD [3-5] and other international organizations, the main way to protect the environment and meet the growing resource needs is to adopt a model of sustainable development. Most developed countries have come to realize the fact that the formation of a balanced environmentally oriented model of economic development is the main condition and the main component of the transition to sustainable development.

In the Republic of Belarus, the National Action Plan for the Development of a Green Economy until 2020, the National Strategy for Socio-Economic Development until 2030 take fully into account the current global environmental problems and determine the priority areas of a green economy and sustainable development [6, 7].

\section{Results and Discussion}

An effective environmental and economic policy requires a wide range of measures. However, when addressing issues of ensuring the environmental safety of the state, issues of efficient use of financial resources are particularly relevant. They should be solved with the help of an active financial policy and an appropriate mechanism for the accumulation, distribution and use of funds.

The financial mechanism for ensuring environmental safety is designed to ensure the implementation of the targeted functions of a social state, which consist in solving a set of social and protective tasks, creating conditions for the development of civil society, in shaping a healthy social and environmentally safe climate, which will eventually lead to a dynamic and sustainable economic 
development of the country. Using only direct methods of influencing users of nature based on relations of power and subordination is not always effective. Accordingly, it becomes necessary to use financial instruments and levers based on material interest, i.e., on indirect state management of environmental safety.

The purpose of the financial mechanism to ensure environmental safety and environmental protection is to harmonize the financial and environmental interests of social production.

According to the authors, extremely insufficient attention has been paid to the nature and content of the financial mechanism for ensuring environmental safety. In addition, financial and economic mechanisms are considered in the aggregate, not highlighting the individual categories. The authors of this study propose to consider the financial and economic systems as relatively independent phenomena, which is caused by the need to use the functional capabilities of the financial mechanism in solving environmental safety issues.

The authors adhere to the point of view that the financial mechanism for ensuring environmental safety should be viewed as an interconnected and interdependent financial management system through financial methods, levers and instruments of public administration in the field of ecology, based on regulatory and informational support.

Based on the study of points of view of domestic and foreign scientists [8-10], the authors have identified approaches to the content and components of state policy in the field of environmental safety. This allowed, based on the research Esina E. [11], systematize the structure of the financial mechanism for ensuring the environmental safety of the state and highlight the main elements in it. The following components of the mechanism under study differ from the approaches that previously existed in the scientific community with a clear structure and depth of detail. This allows us to consider the situation in the field of financial instruments of environmental safety in a comprehensive and systematic way.

I-financial methods, including:

- financial planning and forecasting;

- financial control and audit;

- financing of environmental activities;

- financial normsandregulations;

- financial incentives for environmental activities of business entities;

- financial responsibility for violation of nature conservation legislation;

- environmental taxation;

- environmental insurance;

- leasing of environmentally friendly industrial technologies and environmental protection equipment.

II - financial leverage and instruments, including:

- types and forms of financial plans and forecasts for the implementation of environmental programs;

- budget subsidies;

- use of resources from targeted extra-budgetary environmental funds;

- attraction of extra-budgetary funds;

- investment in the development of environmentally friendly industries;

- environmental taxes, fees and charges;

- taxbreaks;

- accelerated depreciation of fixed assets for environmental purposes;

- financial sanctions for violation of environmental legislation;

- charges and fines for the placement of environmentally harmful substances;

- administrative fees for licensing and others;

- increased rates of payments for violation of environmental standards.

III - financial management:

- statelegislatures;

- financial authorities;

- revenue administrators of the budget system;

- external financial control and budget audit agencies;

- credit managers;

- insurance companies;

- financial departments of enterprises, organizations;

- leasing companies;

- the apparatus of non-profit organizations implementing environmental programs.

IV- organizational support, including:

- legal (legislative acts, decrees of the President, government decrees, orders and letters of ministries and departments and other legal documents);

- regulatory (instructions, guidelines, other regulatory documentation);

- informational.

The effective operation of the financial mechanism is possible only in conditions of the relationship and interdependence of its structural elements. In turn, all the component parts of the control mechanism under consideration contain specific types of impact on users of nature, that is, they themselves are systems.

The practical implementation of a financial mechanism for ensuring environmental safety, including "green" investment, involves the use of various financing instruments, which are presented in Table 1 [12].

The material which is presented in Table 1 allows us to conclude that financial instruments for ensuring environmental safety are not fully implemented in the Republic of Belarus: there is no ecological insurance, a system for trade in pollution rights, leasing of safe industrial technologies and environmental protection equipment, and others. The system of environmental taxation and financial incentives 
for the environmental activities of economic entities require improvement.

Table 1 - Green Investment Financing Tools

\begin{tabular}{|c|c|c|c|c|c|c|c|c|}
\hline 竧 & 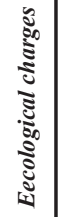 & 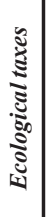 & 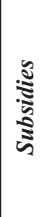 & 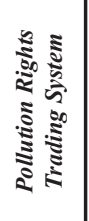 & 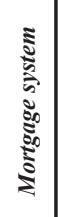 & 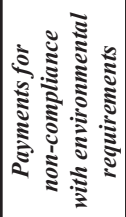 & 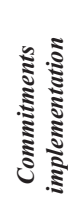 & 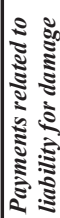 \\
\hline Australia & + & & + & + & + & & + & \\
\hline Austria & + & + & + & & + & & & \\
\hline Belgium & + & + & & & & & & \\
\hline GreatBritain & + & + & & & + & & & + \\
\hline Hungary & + & + & & & + & + & & \\
\hline Germany & + & + & & & & & & + \\
\hline Greece & + & & + & & & + & & \\
\hline Denmark & + & + & + & + & + & & & + \\
\hline Iceland & + & + & & & + & & & \\
\hline Italy & + & & & & + & & & \\
\hline Canada & + & & + & + & + & + & + & + \\
\hline Korea & + & & & & + & + & & \\
\hline Mexico & + & + & & & + & & & \\
\hline Netherlands & + & + & + & & + & & & \\
\hline Norway & + & + & + & & + & + & & \\
\hline Poland & + & + & + & + & + & + & & \\
\hline USA & + & + & + & + & + & & + & + \\
\hline Turkey & + & . & + & & + & + & & + \\
\hline Finland & + & + & + & & + & & & + \\
\hline France & + & & + & + & & & & \\
\hline CzechRepublic & + & ++ & + & & + & + & & \\
\hline Switzerland & + & + & + & + & & & & \\
\hline Sweden & + & + & + & & + & + & & + \\
\hline Japan & + & + & + & & & & & + \\
\hline Russia & + & + & + & & & & & \\
\hline $\begin{array}{l}\text { Armenia } \\
\text { Belarus }\end{array}$ & $\begin{array}{l}+ \\
+\end{array}$ & $\begin{array}{l}+ \\
+ \\
+\end{array}$ & $\begin{array}{l}+ \\
+\end{array}$ & & & & & \\
\hline Kazakhstan & + & + & + & & & & & \\
\hline Kyrgyzstan & + & + & + & & & & & \\
\hline
\end{tabular}

According to the authors, one of the possible ways to efficiently use financial resources to ensure the environmental safety of the state could be the creation of a system of incentives for enterprises whose high revenues coincide with a small amount of harmful emissions. Thus, according to the proposed approach, when calculating environmental payments, it is necessary to take into account both the emissions of pollutants and the company's revenue. Such a ranking of enterprises for two productive factors allows you to create an acceptable set of options and, on their basis, to develop preferential coefficients on environmental tax.

When developing a system of preferential coafficients, the principle of fairness must be taken into account: an enterprise that has the greatest impact on the environment will be subject to a higher tax than before, which should stimulate this organization to revise its environmental policy.

Ecological tax is included in the calculation of the cost of production, so reducing its amount ultimately affects the decrease in the selling price of products. Accordingly, the goods offered by such organizations will become more accessible to the consumer. Moreover, the legislator has the right to provide for a reduction in payments to the budget of the environmental tax amounts, provided that the payer uses these saved resources for environmental protection measures (for example, the introduction of new technologies, developments and equipment). In addition, the option of not charging an environmental tax on enterprises during the period of updating the main technological equipment is possible.

According to the authors, in addition to improving the overall efficiency of the system of using resources for the greening of the economy, the proposed approach will provide the state with a new information resource regarding the volume of organizations participating in environmental pollution.

Further in the publication we will consider the experience of European countries in levying an environmental tax on mobile emission sources and the possibilities of its use for the Republic of Belarus.

The relevance of considering this financial instrument is extremely high. According to the European Environment Agency's indicators [13], automobiles account for almost three quarters of all harmful emissions into the atmosphere. Ecological harm of motor transport is expressed in emissions of exhaust gases, noise emissions, deterioration of landscapes.

In Europe, apply environmental tax on motor vehicles. In France, it is levied on all vehicles registered domestically or abroad, if the permissible total weight of the vehicle exceeds 3.5 tons and driving along the 15,000 $\mathrm{km}$ long taxable national and regional network of France [14].

The payment is calculated in depending on the distance traveled by the taxable network of highways. The sum is calculated on the basis of the collection rate per kilometer, which is determined by the category of car and may vary depending on the level of pollutants in the vehicle exhaust gases (exhaust emission class (European standard), geographical area (remoteness principle: a reduced rate is provided for a number of regions) and road congestion levels [14].

In Germany, issues of environmental hazards of transport are manifested through a tax on car ownership. Only wheelchair users are exempted from its payment. The amount charged depends on the engine size, the type of fuel and the amount of $\mathrm{CO} 2$ emitted into the 
atmosphere. Each $100 \mathrm{~cm} 3$ cylinder volume will cost the owner of a vehicle that consumes gasoline at $€ 2$ per year. For diesel engines, the tax is much higher $-9.5 €$ per 100 $\mathrm{cm} 3$. But this is if the diesel engine is equipped with a particulate filter. Without it, the tax is even more: $10.7 €$ per $100 \mathrm{~cm} 3$ [15].

The second component of the tax is determined depending on the weight of carbon dioxide emitted into the atmosphere per 100 kilometers. Here, each gram will cost another $€ 2$ per year [15].

Within the tax under consideration, motor vehicles should be understood as automobiles and trailers. It is possible not to consider vehicles that are used to clean the streets as it is done in other European countries, for example, France and Germany, as objects of taxation.

According to the State Automobile Inspectorate of the Republic of Belarus, every third resident of the country is the owner of a motor vehicle.

For the fairness of charging, it is necessary to establish tax rates for different types of fuel, taking into account the uneven impact of their emissions on the environment (for example, taking the tax rates in Germany as a basis and adjusting them for the income of the population of the Republic of Belarus). Further, it is necessary to introduce different coefficients to the tax rate for different engine volumes, since the amount of fuel consumed by the vehicle depends on it. This will encourage owners to buy newer vehicles, emissions from which do not exceed the norm. Imagine the possible correction factors to tax rates in table 2 .

TABle 2 - Possible Correction Factors for TAX

RATES

\begin{tabular}{|c|c|c|c|c|c|}
\hline \multicolumn{2}{|c|}{$\begin{array}{c}\text { Vehicleweight } \\
\text { Up to 1,1 }\end{array}$} & \multicolumn{4}{|c|}{$\begin{array}{c}\text { Engine Capacity, } \\
\text { In Liters }\end{array}$} \\
\cline { 3 - 6 } & $\mathbf{1 , 2 - 1 , 5}$ & $\mathbf{1 , 6 - 3 , 5}$ & $\begin{array}{c}\text { Over } \\
\mathbf{3 . 5}\end{array}$ & \\
\hline $\begin{array}{c}\text { up to } \\
3.5 \\
\text { tons }\end{array}$ & $\begin{array}{c}\text { Passenger } \\
\text { cars }\end{array}$ & 0,5 & 0,75 & 1,25 & 1,5 \\
\cline { 2 - 6 } & Freight & 0,75 & 1 & 1,5 & 1,75 \\
\hline \multicolumn{3}{|c|}{ over 3.5 tons } & \multicolumn{5}{|c|}{2} \\
\hline
\end{tabular}

According to the authors, a reduction factor should be introduced for vehicles using the safest types of fuel - 0.2.

Taxation of mobile sources will encourage taxpayers to use machines with the lowest fuel consumption, in order to reduce harmful emissions. If the taxpayer chooses a car with high fuel consumption, then such a decision will have to pay a more substantial amount of environmental tax. As in the case of the tax from stationary sources, the approach to which we considered above, the principle of justice also works here. An entity that has a significant environmental impact will pay more than a taxpayer with micro or small cars.

The introduction of a motor transport tax in the Republic of Belarus will in many ways stimulate the development of public transport and the development of systems for effective purification of exhaust gases, the use of which in the future will improve the quality of life of the population of the Republic of Belarus.
Ecological insurance is recognized as an independent element of financial support for the mechanism of environmental protection, which makes it possible to define it as one of the effective ways to ensure the environmental safety of the state.

At the moment, the Republic of Belarus is far behind European countries in the use of this financial instrument. However, the systematic introduction of European conceptual directions of ensuring environmental safety into the practice of the state policy of the Republic of Belarus will make it possible to radically change the situation. To this end, it seems necessary to fix a clear definition of the concept of "environmental insurance" in the Law of the Republic of Belarus "On Environmental Protection". Further, at the legislative level, determine the place of environmental insurance in the system of insurance relations of the Republic of Belarus as an independent type of liability insurance for harm. It is possible to implement this task by making appropriate amendments to the provision "On insurance activities in the Republic of Belarus", approved by decree of the President of the Republic of Belarus of August 25, 2006 No. 530. This will serve the Republic of Belarus as a significant step towards the development and adoption of a package of regulatory legal acts regulating a special sphere of public relations in the field of liability insurance for harm caused by harmful effects on the environment.

\section{Conclusions}

From the above materials of the article it can be concluded that at the present stage of socio-economic reforms carried out throughout the world, one of the key problems of further development of the national economy is the fundamental problem of the imbalance between sustainable economic growth and the preservation of natural capital. This situation leads to the actualization of the use of the most progressive financial instruments to ensure the environmental safety of the state.

The systematization of theoretical and practical materials carried out by the authors of the article made it possible to identify the main elements of the financial mechanism for ensuring environmental safety. Analysis of the use of individual financial instruments of the mechanism under study, both in European countries and in the Republic of Belarus, allowed the authors to suggest ways to improve their use in practice.

The application of the proposed directions for improving the financial mechanism for ensuring the environmental safety of the state in practice will allow: to ensure an increase in the level of efficiency in the use of collected resources for restoration and protection of the environment; increase the incentive function of the environmental tax; introduce the most progressive experience of foreign countries.

The increasing complexity of economic relations, the development of market relations entail the improvement of the already established, as well as the emergence of new elements of the mechanism aimed at ensuring resource-saving environmental management and environmental protection. These include, for example, the 
creation of a market for natural resources, the sale of rights to a certain amount of environmental pollution, a "pledge-return" system that is actively used in some foreign countries.

\section{REFERENCES}

[1] D.H. Meadows, J. Randers, D.L. Meadows, and W.W. Behrens, The Limits to Growth: A Report for the Club of Rome's Project on the Predicament of Mankind. Universe Books, 1972.

[2] V.I. Vernadsky, Chemical structure of the Earth's Biosphere and its environment. Moscow: Nauka, 2001.

[3] Towards a Green Economy: Pathways to Sustainable Development and Poverty Eradication UNEP, 2011Summarizing report for government representatives. [Online]. Available: $\quad$ https://sustainabledevelopment.un.org/index. php? page $=$ view $\&$ type $=400 \& n r=126 \&$ menu $=35$ [Accessed: Nov. $25,2018]$.

[4] UN Environment Annual Report 2017. [Online]. Available: https:// www.unenvironment.org/resources/un-environment-annualreport-2017 [Accessed: Nov. 26, 2018].

[5] OECD Indicators "Environment at a Glance 2015". [Online]. Available: https://www.amazon.com/Environment-At-GlanceOECD-Indicators/dp/9264235183 [Accessed: Dec. 26, 2018].
[6] Council of Ministers of the Republic of Belarus. National Action Plan for the Development of a Green Economy in the Republic of Belarus until 2020. Minsk, 2016.

[7] Council of Ministers of the Republic of Belarus. National STRATEGY FOR SUSTAINABLE SOCIO-ECONOMIC DEVELOPMENT OF THE Republic of Belarus until 2030. Minsk, 2017.

[8] E.V. Girusov, Ecology and Economics of Environmental Management. M .: UNITI, 1998.

[9] Ya. Ya. Yandyganov, Environmental Economics. Moscow: KnoRus, 2005.

[10] Z. A. Kesyan"Economic aspects of ensuring environmental safety at the micro level," Bulletin of Adygea State University, № 4, 2010, pp. 28-34.

[11] E.I. Esina"Formation of an effective financial mechanism of state policy in the field of ensuring environmental safety,"Economic issues, №17(107), 2012,pp. 37-44.

[12] K.V. Papenov, E.S. Melekhin"Improving the economic mechanism of subsoil use in modern conditions, "Bulletin of Moscow University, №1, 2002, pp. 36-56.

[13][13] European Environment Agency. Air pollutant emission. [Online]. Available:

[14] https://www.eea.europa.eu > ... > Data and maps > Indicators [Accessed: Dec. 3, 2018].

[15] France. Ecological tax. Association of International Road Carriers. [Online]. Available: http://bamap.org/information/news.[Accessed: Nov. 18, 2018].

[16] [15] The cost of maintaining a car in Germany. Life in Germany. [Online]. Available: https://www.tupa-germania.ru/avtomobil/ 